\title{
Analyzing the Impacts of Climate Change on Water Level Fluctuations of Tashk and Bakhtegan Lakes and Its Role in Environmental Sustainability
}

\author{
Tayebeh Kiani ${ }^{1}$, Mohammad Hossein Ramesht ${ }^{1 *}$, Amjad Maleki², Faridah Safakish ${ }^{3}$ \\ ${ }^{1}$ Faculty of Geographical Sciences and Planning, University of Isfahan, Isfahan, Iran \\ ${ }^{2}$ Faculty of Literature and Humanities, Razi University, Kermanshah, Iran \\ ${ }^{3}$ Faculty of Geographical Sciences, University of Kharazmi, Tehran, Iran \\ Email: *mh.raamesht@gmail.com
}

How to cite this paper: Kiani, T., Ramesht, M.H., Maleki, A. and Safakish, F. (2017) Analyzing the Impacts of Climate Change on Water Level Fluctuations of Tashk and Bakhtegan Lakes and Its Role in Environmental Sustainability. Open Journal of Ecology, 7, 158-178.

https://doi.org/10.4236/oje.2017.72012

Received: November 14, 2016

Accepted: February 24, 2017

Published: February 27, 2017

Copyright $\odot 2017$ by authors and Scientific Research Publishing Inc. This work is licensed under the Creative Commons Attribution International License (CC BY 4.0).

http://creativecommons.org/licenses/by/4.0/

cC) (i) Open Access

\begin{abstract}
Climate changes are the main motivation for destruction of ecosystems; in fact the effects of these changes on biodiversity and ecosystems are considered as the most challenging cases in present century. Therefore, since the lakes are the most important services and functions of ecosystems, the effect of climate change on water level fluctuations of Tashk and Bakhtegan Lakes was analyzed as a natural ecosystem in this essay. For this purpose, the data related to six parameters of temperature, precipitation, evaporation, sunshine hours and snowy days were selected during 25-year statistical period (1985-2010), and Mann-Kendall test was used to determine the trend of changes in each time series. Inflow system of the lake, the volume of evaporation and area of water were simulated and fluctuation of lake was also assessed by using dynamic analysis method and to achieve to lake level and analysis of its fluctuations in period under study, the satellite images of Landsat 7 and ETM 5-1 were used in two high waters of April 1987 and April 2010. Results indicate that the lake level has been dropped 6 meters in 2010 compared to the similar period of 1986; in wet years that the rainfall is more than $618 / 5 \mathrm{~mm}$, high water level is the lake conditions in all months of the year; unlike in most years when rainfall occurred under average of $365.4 \mathrm{~mm}$, lake is faced with dry condition that is mainly due to the reduce of icemaker area, rainfall reduction, increase in evaporation and temperature. These conditions show the extent to which the lake is fragile and affected by climatic conditions that the most obvious evidence of it is decline of genetic storages such as Tashk and Bakhtegan lakes and subsequently instability of the region and reducing of services and ecosystems' functions.
\end{abstract}




\section{Keywords}

System Analysis, Simulation, Tashk and Bakhtegan Lakes, Climate Change

\section{Introduction}

In order to enhance and protect the resilience of the Great Lakes, predicting future outcomes of climatic changes, particularly in already degraded geographical areas is instrumental to success. These changes include warming air and water temperatures; shifts in the timing, severity and frequency of precipitation events and storms; varying lake levels; and reductions in lake ice cover [1]. Surface water bodies are a key component of a wide variety of ecosystem services (e.g., [2] [3]). Lake water level regimes are influenced by climate, hydrology and land use [4]. Increased temperatures could have implications for Great Lakes water levels [5]. This issue is even more crucial when it comes to arid and semi-arid regions of the world [6] [7] [8]. Actually, in recent years fluctuations of the basin water levels are influenced by changes in precipitation, evaporation, and evapo-transpiration [9] and these water bodies have been significantly affected by global warming and climate change [10], and lake levels are likely to continue to fluctuate. On the other hand, due to increasing water consumption in dry regions, lakes and other aquatic ecosystems are under increasing pressure [11] [12] [13]. Therefore, with respect to the destruction aquaticecoseco system and knowing this subject that climate change has a significant impact on the natural hydrological cycle and amplifies water scarcity in (semi)-arid regions [14] [15] [16], understanding the effects of temperature increases on patterns of biodiversity is of fundamental importance to quantifying the ecological and economic risks of climate change [17] that the responses in lake water levels can be used as an indicator to assess the overall regional hydrological impacts of climate change, land use change and river regime modifications [4] [11] [13] [18]-[23].

According to the above information and with respect to the direct and indirect impacts of climate change on biodiversity and eco system processes, among all the effects of climate changes the impacts on biodiversity and ecosystems are among the key reasons for concern about climate change [17]. Significant impacts of climate change on biodiversity have been observed already [24] [25] and future potential changes in climate will adversely affect species and habitats [26] [27]. On the other word, human-forced climate change and ongoing environmental degradation leading to habitat loss and fragmentation threaten the future of the world's biodiversity [28] [29]. These threats include extinction, decreased population abundance, reduced genetic diversity, lower reproductive success, lower dispersal ability, increased vulnerability to stochastic events, increased susceptibility to invasive species, simplified trophic structure and altered interspecies interactions [30] [31] and climate change is an important cause of the irreversible transformation of habitats, of the rapid extinction of species [32]. Generally, the experts believe that climate change will become increasingly im- 
portant among the major drivers of direct (and in-direct) habitat and species loss [33] [34], along with cascading impacts on other eco system services [35]. According to fact that the climate change entailing likely increases in temperature and regional and seasonal changes in precipitation [36], ecosystems and their services are likely to suffer additional stresses [37] [38] [39] and continuing increase temperature present century. Accessing data relating to the latest status of water bodies in these regions has always been a challenge [40]. Hence, it is of great importance to acquire a full archive of these changes for environmental management and planning purposes [41] [42]. Because severe impacts in lake ecological [43] and socio-economic status have been reported for many large and small lakes worldwide, such as the Aral Sea in Asia [44]-[47], Lake Chad in Africa [48] [49] and the Great Salt Lake [50] [51] and the Salton Sea [52] [53] in the United States. Climate change has been a topic of interest for many researchers: the effects of climate change to increase level of Victoria Lake in east of Africa were analyzed by Mistry and Conway (2003). The results showed that there were direct relation and correlation between fluctuation of lake's level and precipitation on the lake surface [54]. Findings of Guo et al. (2006) showed that because of severe impact of region's weather on water surface of Poyang Lake and water sources in China, it is expected that the hydrological processes and water evacuation to the lake will be changed in the future [55]. Mendoza et al. (2006) in an effort analyzed the reasons of Cuitzeo lake's changes in Mexico; they used statistical models to link fluctuations of water level to rainfall and temperature; for this purpose the time series was used [56]. Ryner et al. (2007) in the post-glacial warm period studied the restoration of local response of lake to regional climate change and hydrological instability [57]. Motiee and Makbin (2009) also found that the climate change causes to reduce $50 \mathrm{~cm}$ water level of the Superior Lake located on North America that is the lowest amount in the past 81 years. They also found that in a short period of time, water level of lake has been decreased one centimeter in every year and given to obtain results they found that these changes can indicate signs of climate change phenomenon in the studied area [58]. Zilefac (2010) showed that by reducing rainfall and increasing temperature the average depth of Chad Lake has fallen from about 7 meter to 1.5 meter [59]. Njaya et al. (2011) stated that average depth of Chilwa Lake has been decreased from 0 to 12 meters between 1960 and 2000 [60], Huang et al. (2011) considered the temperature and precipitation as the most important factors affecting on fluctuations of Cottonwood Lake in United State [61]. Mekonnen et al. (2012) pointed out that depth of Naivasha lake has been decreased 4 meter between 1965 and 2001 [62] and finally Zaviska et al. (2015) by using results of several indexes analysis (palynology, sedimentology, chemical composition and paleontology) clearly showed that weather has been the main motivation of change in aquatic and terrestrial ecosystems as well as geomorphologic processes of eastern Poland basin [63].

Therefore, considering the fact that the Middle East especially Iran is one of the most important areas that is affected by global warming, and is considered 
one of the most vulnerable areas affected by climate change due to reduced rainfall, and in the other hand lakes and ponds in arid regions are the field of important ecosystem services, such as weather moderating and food supply and have determinative role as a resources of surface waters. Tashk and Parishan lake is a freshwater wetland located in southern west of Fars province that has not been of interest unlike Uremia lake, this lake is very susceptible to climate changes for reason that the lake basin is closed and it has greatly been changed over the past decades, for this reason it has been studied. Given to the importance of climate change in water crisis of Tashk and Bakhtegan lakes it has been tried to pay attention to analysis and simulation of lake level under conditions of climate change after assessing of basin climate change by using output of datadriven mode.

\section{Procedures and Methods}

\subsection{The Studied Area and Data Usage}

Tashk and Bakhtegan lakes located in southern west of Fars province is the most important habitats and is considered as a second largest lake inside of Iran and is located about 1476 to 3909 height. These lakes are fed by some rivers and precipitation on its surface and surrounding area, but during the evaporation process a significant amount of water exited from this system. Generally the extents of catchment are about 2721.656 hectare and are fed by Kor River. The studied catchment basin is located between latitude of $29^{\circ} 2^{\prime} 50^{\prime \prime}$ to $31^{\circ} 14^{\prime} 29^{\prime \prime}$ Northern and longitude of $51^{\circ} 42^{\prime} 15^{\prime \prime}$ to $54^{\circ} 31^{\prime} 10^{\prime \prime}$ Eastern (Figure 1).

\subsection{Method}

For doing this study, the monthly data of temperature average, precipitation, relative humidity, sunshine hours and snowfall days of synoptic stations affiliated with the Country General administration of Meteorology as well as monthly flow rate data and evaporation-measuring of station subordinate of Ministry of Power during 1985-2010 were used (Table 1). And to achieve the area of lakes and analyzing their fluctuation in the under studied period the satellite images of Landsat 7 and ETM 5-1 have been used.

In assessing the regional effects of climate change, first of all time series of climate variables is needed. For making these data, it is required to use the statistical methods for study the past trend and generalization of it in future of produced data; for analyzing the studied climatic elements and to measure the occurred changes in basins; Mann-Kendall trend test is used. This test was suggested by World Meteorological Organization in 1988 that in a significant assessment the climate data series trend is used in many studies. In such a way that the statistical series are arranged and ranked in ascending order, in this test random data are specified by lack of process. Mann-Kendall rank correlation is such a ranking correlation that will be obtained given to the numerical rating from 1 to Equation (1) 


$$
r_{2}=\frac{\sum_{i=1}^{n-1} \sum_{j=i+1}^{n} \operatorname{sgn}\left(a_{1}-a_{n}\right)}{\frac{1}{2} n(n-1)}=\frac{p}{\sqrt{\frac{1}{18}}\left[n(n-1)(2 n+5)-\sum b_{1}\left(b_{1}-1\right)\left(2 b_{1}+5\right)\right]}
$$

In this equation $b_{1}$ is number of similar data (duplication), $n$ is length of statistical period, sgn is algebra symbol of both couples undergoing ratings in $\left(a_{i}-a_{j}\right)$ which $i>j$ it means rating difference is $i$-th and $j$-th that the fourth relation is governed in it.

$$
\operatorname{sgn}\left(a_{1}-a_{n}\right)=\left\{\begin{array}{cc}
1 & a_{i}>a_{j} \\
0 & a_{i}=a_{j} \\
-1 & a_{i}<a_{j}
\end{array}\right\}
$$

For analyzing the slope value of timeline available in meteorological data as well as output of system's dynamics analysis the univariate linear regression was used Equation (2).

$$
y=b x+a
$$

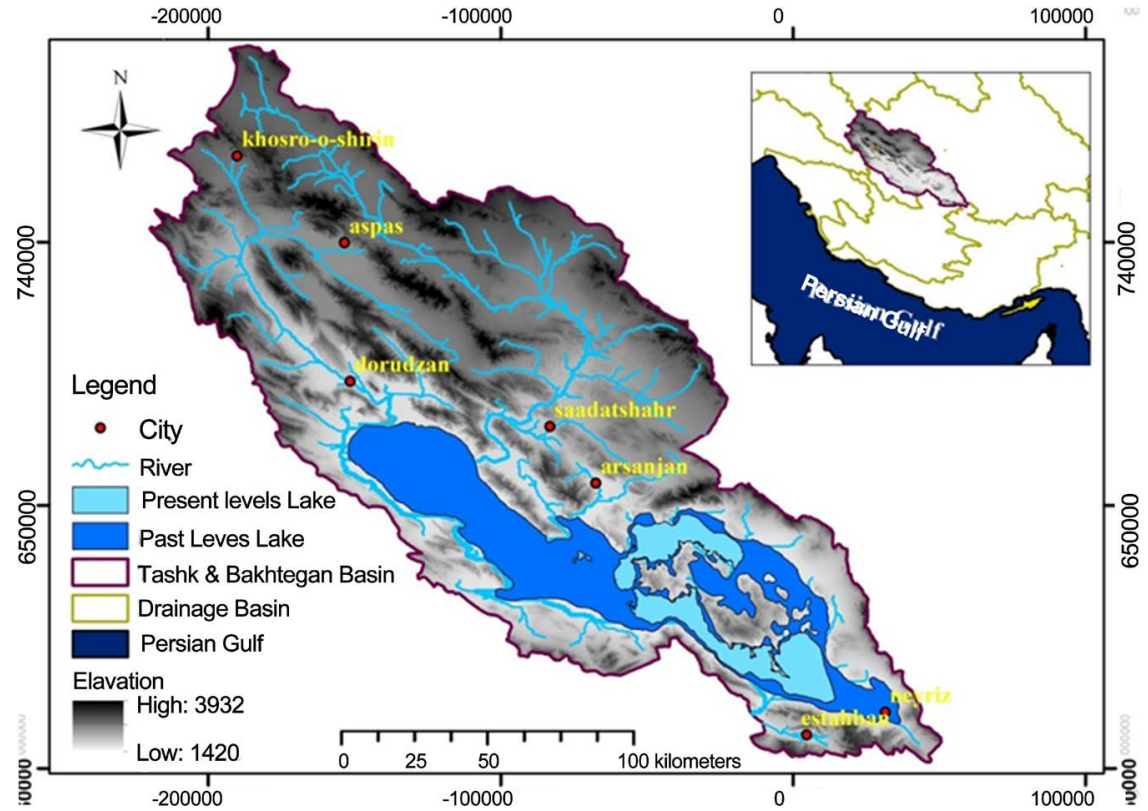

Figure 1. Location of Tashk and Bakhtegan catchment basin in Iran and its height condition.

Table 1. Introduction and locations of used stations in research.

\begin{tabular}{cccccc}
\hline Order & Station name & Type of station & Longitude & Latitude & $\begin{array}{c}\text { Length of } \\
\text { statistical period }\end{array}$ \\
\hline 1 & Bolaghi Gorge & Hydrometer & 53.17 & 30.17 & $2010-1985$ \\
2 & Dasht Bal & Pluviometer & 52.81 & 30.01 & $1985-2010$ \\
3 & Droudzan Dam & Synoptic & 52.45 & 30.1 & $1985-2010$ \\
4 & Khan Bridge & $\begin{array}{c}\text { Flow rate } \\
\text { measuring }\end{array}$ & 52.77 & 25.81 & $2010-1985$ \\
\hline
\end{tabular}


In the above formula $y$ is dependent factor, $a$ is intercept, $b$ is slope of the line and $X$ shows independent factor. In this formula $a$ and $b$ are obtained from Equation (3) and (4):

$$
\begin{gathered}
a=\frac{\sum y-b \sum x}{N} \\
b=\frac{N \sum \cdot X Y-\sum X \cdot \sum Y}{N \sum x^{2}\left(\sum_{x} 2\right)}
\end{gathered}
$$

\section{Standardized Precipitation Index [SPI]:}

To analyze the droughts and drought severity in the region the standardized precipitation index [SPI] was used. This index is the most important index of drought assessment that was invented by Maki et al. [179-184: 1993]. This index is dimensionless that is calculated from irregularities of separated and converted data of precipitation which is divided on the standard deviation of rainfall Equation (5).

$$
S P I=\frac{(P-\bar{P})}{s d}
$$

In which $S P I$ is standardized precipitation index, $p$ is annual precipitation, $\bar{P}$ is statistical period precipitation average and $s d$ is standard deviation of statistical period precipitation. This index is applied based on the probability of rainfall for different time scales that it can also predict drought conditions before outbreak of the event and it can help to estimate drought severity. In the following in order to achieve to lake level and analyzing its fluctuations in period under study, thesatellite images of Landsat 7 and ETM 5-1 were used in two high water of [April 1985 and April 2010].

\subsection{Climate Analysis of Tashk and Bakhtegan Basin}

To analysis climate change in the region and its effect on lakes and its role on environmental instability, changes process of rainfall, temperature, evaporation, sunshine hours and snowy day's parameters were studied. For this purpose, synoptic monthly data with 25 years statistical period have been used. Monthly data of catchment basin of Tashk and Bakhtegan were considered as independent parameters and their time series were analyzed during the desired period. Climate parameters of Tashk and Bakhtegan basin were monthly evaluated (Table 2), so that in monthly scale, the average temperature of basin is increased to 0.004 centigrade by 0.32 trends; the amount of basin rainfall and snowy days respectively decreased to 0.05 and $0.01 \mathrm{~mm}$ and its trend were 0.05 and 0.09 . Sunshine hours and evaporation is also increasing monthly at an average rate of 0.1 and 0.05 and by increasing trend about 0.05 and 0.08 in month. The monthly humidity average has a negative slope of 0.02 and per month $0.003 \mathrm{~mm}$ reduction. The basin also has faced with inflow reduction with 0.1 slope and increase in outflow with slope of 0.1 . Flow rate of basin as well as blue expanse level with 0.9 trends are decreasing, Figure 2 shows monthly changes of time series of climate elements in annual scale of Tashk and Bakhtegan catchment basin during 
period of 1985-2010.

\subsection{Analyzing of Drought Severity in Tashk and Bakhtegan Basin}

In this study, the standardized precipitation index was used for analyzing the basin droughts of under studied lakes. For this purpose, SPI drought index
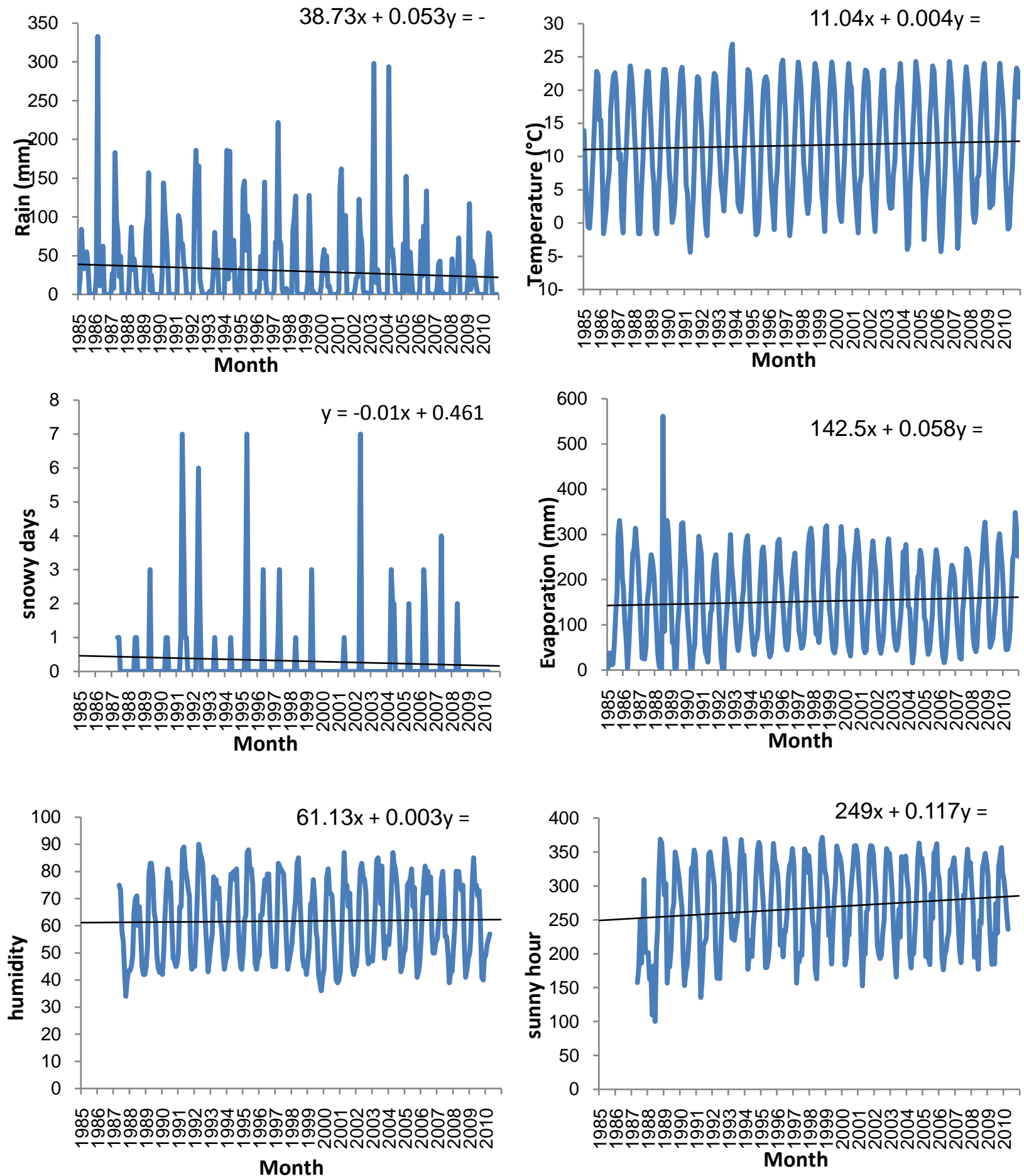

Figure 2. Monthly changes of time series of annual climate elements of Tashk and Bakhtegan catchment basin during the period of 1985-2010. 
calculated in annual scale and different precipitation regimes of basins were calculated based on it and dry year and wet year were obtained based on different conditions monitoring. Therefore, by using SPI index, dry years of basin was analyzed and by considering the amounts of calculated annual SPI it was found that the years of 1992-2003 and 2006-2011 are the periods of drought in the region (Table 3). Given to Figure 3 the amount of dryness is increasing with amount of 0.04 in month.

The most severe dry year was recorded in 2008 with precipitation amounts of $73.07 \mathrm{~mm}$. According to the results obtained from the droughts the severity and frequency of droughts is increasing in Tashk region. Driest year is related to

Table 2. Test of climate parameters change trend by using Mann-Kendall test during the period of 1986-2010 in monthly scale.

\begin{tabular}{cccc}
\hline Parameter & Trend analysis & Parameter & Trend analysis \\
\hline 0.160 & Outflow & -0.058 & Rainfall \\
-0.096 & Snow days & 0.032 & Temperature \\
0.082 & Sun hour & 0.053 & Evaporation \\
0.025 & Humidity & -0.102 & The volume of rainfall \\
-0.44 & Area & -0.11 & The volume of evaporation \\
-0.78 & Level & -0.163 & Flow rate \\
-0.089 & Drought index & -0.199 & Inflow \\
\hline
\end{tabular}

Table 3. Analyzing of drought severity in Tashk and Bakhtegan basin.

\begin{tabular}{cccc}
\hline $\begin{array}{c}\text { The most severe } \\
\text { drought SPI }\end{array}$ & $\begin{array}{c}\text { Year of severe } \\
\text { drought }\end{array}$ & $\begin{array}{c}\text { The longest drought } \\
\text { duration }\end{array}$ & $\begin{array}{c}\text { Duration of drought } \\
\text { period }\end{array}$ \\
\hline$-2 / 8$ & 2008 & $1992-2003$ & 5 \\
& $2006-2011$ & 6 \\
\hline
\end{tabular}

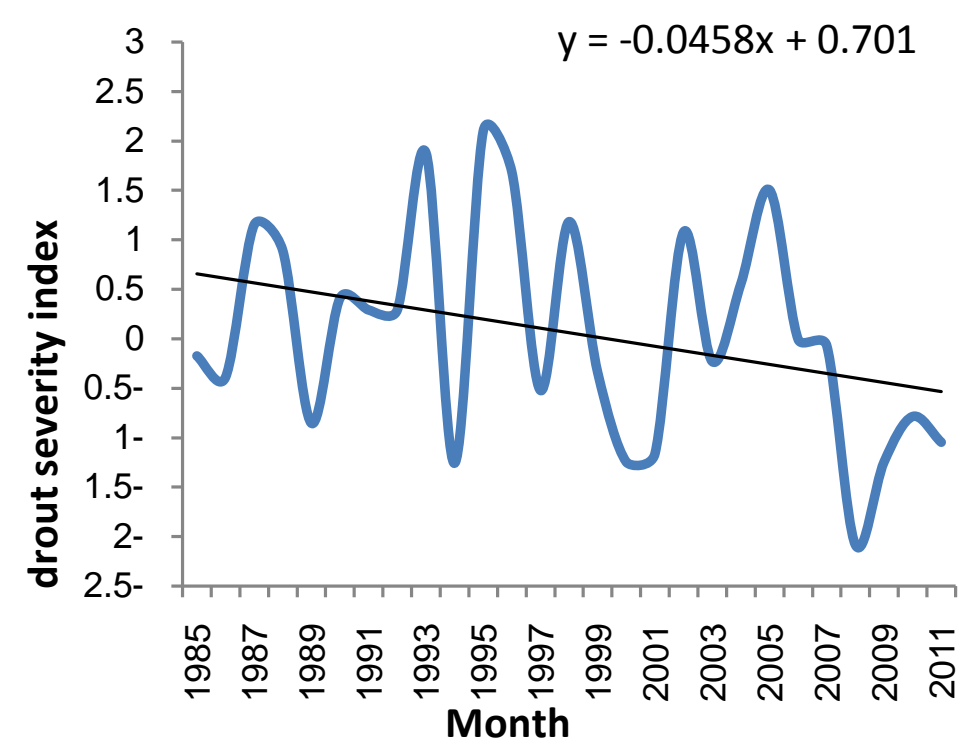

Figure 3. Index of drought severity in Tashk and Bakhtegan basin. 
2008 and wettest year is related to 1995, so that the average precipitation of basin that is 365.4 , in the wettest year reach also to $618 / 5 \mathrm{~mm}$, while in periods of drought reduced to $96.5 \mathrm{~mm}$. This shows $268.9 \mathrm{~mm}$ reduction (73 percent) to the average Table 4. In this basin also the most frequency is related to poor dry year with amount of 37.8 and weak wet year with amount of 26.7.

\subsection{Lake Level Calculation}

Lake level has been reduced 6 meters in 2010 compare to similar time in 1986, that is mainly due to the ice area reduction, precipitation, increase in evaporation and temperature. These circumstances show that the extent to which the lake is fragile and is affected by climate conditions. In many of years with below average rainfall about 365/4 millimeters, lake has suffered from drought. In contrast, in the years with rainfall more than $618 / 5 \mathrm{~mm}$ in wet years, high water is condition of lake in all months. Changes of lake level are seen in Figure 4. Finally after assessing climate changes of basin, System Dynamics simulation method was used to show blue expanse changes of lakes to analyze these changes.

\subsection{System Dynamics Method}

Water resource management requires prospective decisions and design of water development projects with comprehensive and integrated approach. One of the managemental tools based on this view is system dynamic science. This science has capacity to simulation complicated systems of water sources to support decision-making. By helping this simulation, unknown subsequences of decision-

Table 4. Analyzing frequency of drought during period of 1967-2009.

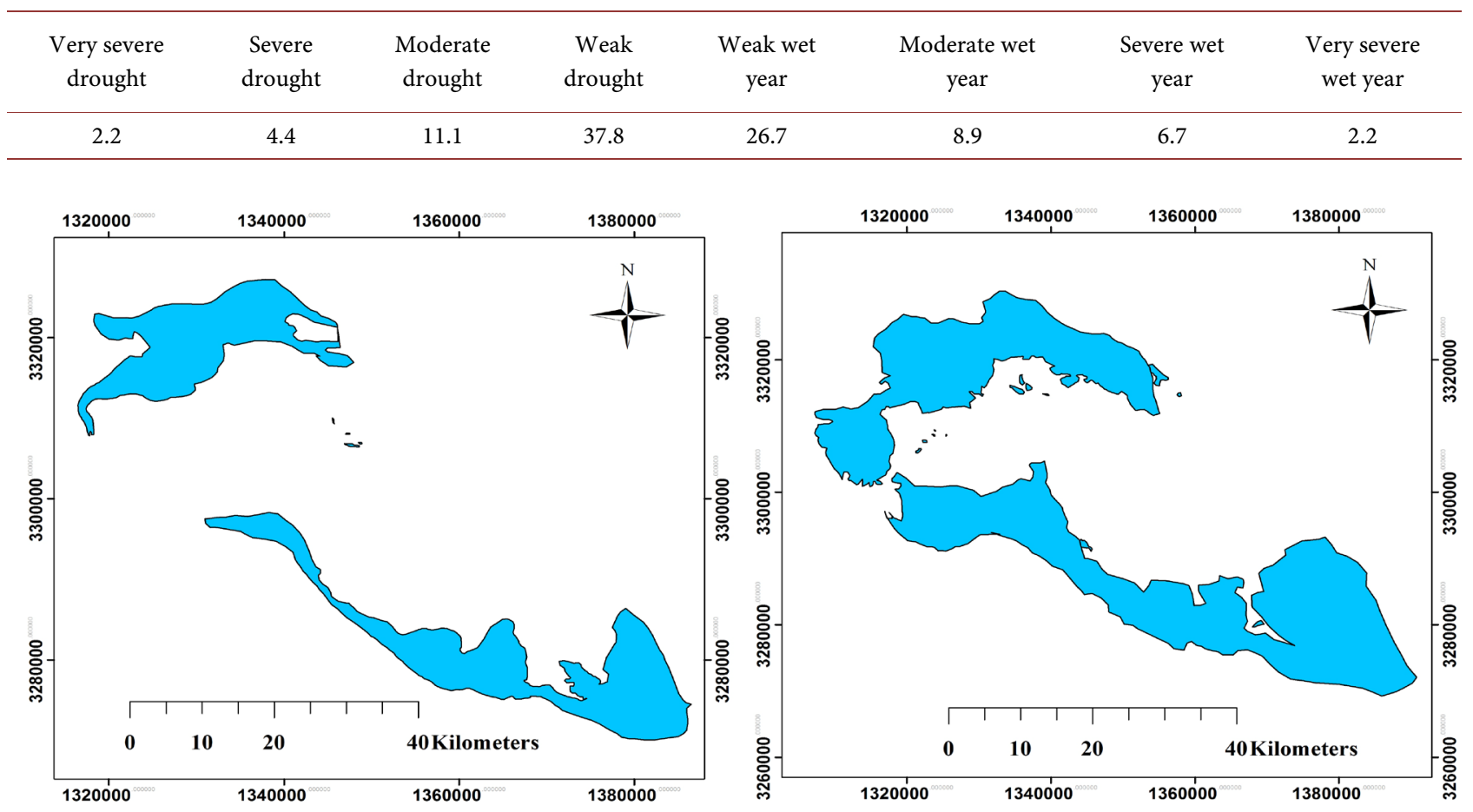

Figure 4. Level changes of Tashk and Bakhtegan lakes by using satellite images in April of 1985 and 2010. 
making will be revealed. Main objective of this simulation method is to accelerate and facilitate of systems' behavior learning in the current and future situation.

System Dynamics model of lakes provide the possibility to study the impact of various factors on lake in separate or simultaneous and systemic form, the model can also predict implementation of new policies in the future by applying changes. This science has capacity to simulation complicated systems of water sources to support decision-making. By helping this simulation, unknown subsequences of decision-making will be revealed. Main objective of this simulation method is to accelerate and facilitate of systems' behavior learning in the current and future situation.

System Dynamics analysis method as a method which is based on systematic thought is a method to study and improve learning in relation with complicated systems, in which by using mathematical modeling, the possibility of simulation, perception and understanding of complicated systems are provided by it, the basis of this simulation method is based on feedback and object-oriented events. In this method, four tools of storage, flowing, connectors, and converters are used and modeler mentality is changed into cause and effect diagrams by them and finally into storage and flow diagrams. The complex of these relations indicates the structure of system [Vlachos et al., 2007]. System Dynamics is established based on two fundamental foundations, the first foundation is to pay attention to time factor in such a way that system's behavior to be analyzed during time. The second foundation is to pay attention to feedback in any system. Modeling steps with systems' dynamic approach include: definition of problem and develop its conceptual model, determination the border of system, determination of dynamic hypotheses, development of the simulation model, verification of model and the use of models for policy analysis. Therefore, since the important events in any system is a feedback role of effective factor of any system, which can be seen in the form of positive and negative feedback in this part by using system dynamic analysis method and climate variables affecting on lake system the feedback analysis of this interaction is analyzed. And to reconstruct and simulation of blue expanse level changes of Tashk and Bakhtegan lakes by using dynamic analysis system, the most important factors affecting the fluctuations of lake level which include inflows, precipitation and evaporation from the surface of the lake were used. System Dynamics model of Tashk and Bakhtegan lakes provide the possibility to study the impact of various factors on lake in separate or simultaneous form, the model can also predict implementation of new policies in the future by applying changes. Feedback role of effective factor on every system is such an important event in any system which can be seen in the form of positive and negative feedback. In this situation it is necessary to understand system dynamic and key variables affecting on it.

\subsubsection{Simulation of Blue Expanse Changes of Tashk and Bakhtegan Lakes by Using System Dynamic Analysis Network}

In this part by using system dynamic analysis model and climate variables af- 
fecting on lake system, the feedback analysis of this interaction is analyzed. To reconstruct and simulation of blue expanse level changes of Tashk and Bakhtegan lakes by using system dynamic analysis network, the most important factors affecting the fluctuations of lake level which include inflows, precipitation and evaporation from the surface of the lake were used. Primary investigation on observations events of temperature, precipitation, snow cover and sea level show changes in this variables. But the impact of these changes is not only on average statistics, but rather the intraclimatic events such as storm, floodwater and droughts are also affected by it.

In order to do these investigations the vensim software box was used. In this scenario, at first the causative and effect circles affecting on lake system of basin should be drawn (Figure 5). If model has only one outflow and one inflow, it is calculated in form of Equation (6).

$$
\operatorname{Stock}\left(t_{n}\right)=\int_{t 0}^{t n}[\operatorname{Inflow}(t)-\operatorname{Outflow}(t) \mathrm{d} t+\operatorname{Stock}(t)]
$$

in which $\operatorname{Stock}(t)$ is lake in time, $\operatorname{Inflow}(t)$ the amount of inflow to the lake in time, Outflow $(t)$ is amount of outflow from the lake in time $a$ and $t$ is time interval between $t$ to $t n$. Lake water volume based on the above mentioned is equal to Equation (7):

$$
\left.V\left(t_{n}\right)=\oint_{t 0}^{n}[R+(t)+S W(t)-E(t)] d t+V(t)\right] \mathrm{d} t+V\left(t_{0}\right)
$$

In which $V$ is volume of lake water at the time of $t, R(t)$ is volume of inflow to the lake at time of $t, S W(t)$ is volume of surface water inflow to the lake in time of $t, E(t)$ is volume of evaporated water from the surface of the lake at the time of $\mathrm{t}$ and $V(t)$ is lake water volume at time of $t$.

To do simulation model, data are recorded monthly and the required equations are written for the relationship between variables. And changes of area, lake water volume and lake water level can be observed.

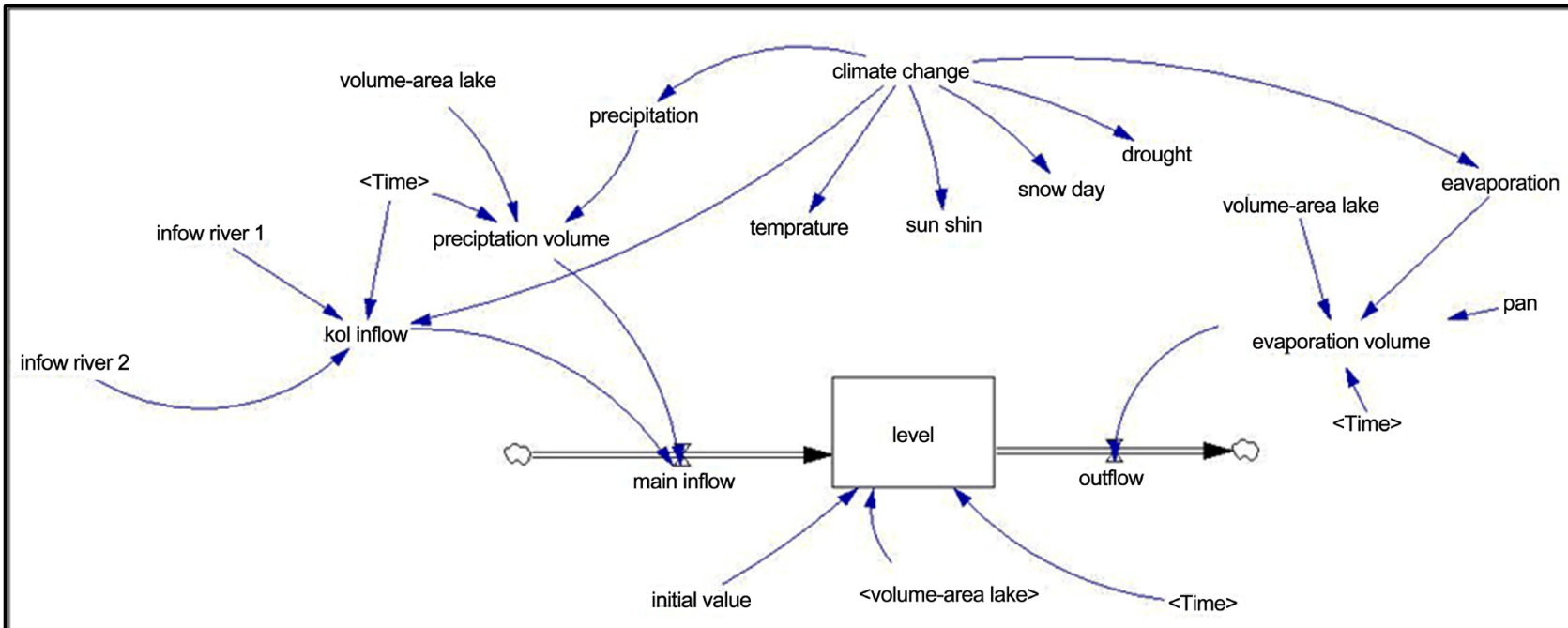

Figure 5. Tashk and Bakhtegan lakes in model of [System Dynamics] and cause and effect relationship. 


\subsubsection{Simulation of Lake Surface Model}

To simulate water surface changes of Tashk and Bakhtegan lakes, vensim model (System Dynamics) was used and changes of blue expanse of basin was analyzed based on the most important factors affecting the fluctuations of lake surface which includes inflow flow rate, precipitation and evaporation from the surface of the lake; for this reason at first it was necessary the inflows to be simulated based on climate changes information (Figure 6) then during 25 years statistical period and in monthly separation it was defined as a model and according to the conducted evaluation on intended variables (flow rate, precipitation, show decreasing trend and temperature and evaporation show increasing trend); given to the calculated flow rate as well as using precipitation data and estimated temperature under climate change scenarios and Vensim network model application the blue surface of lake is simulated to 2010 and results are presented in Figure 7.

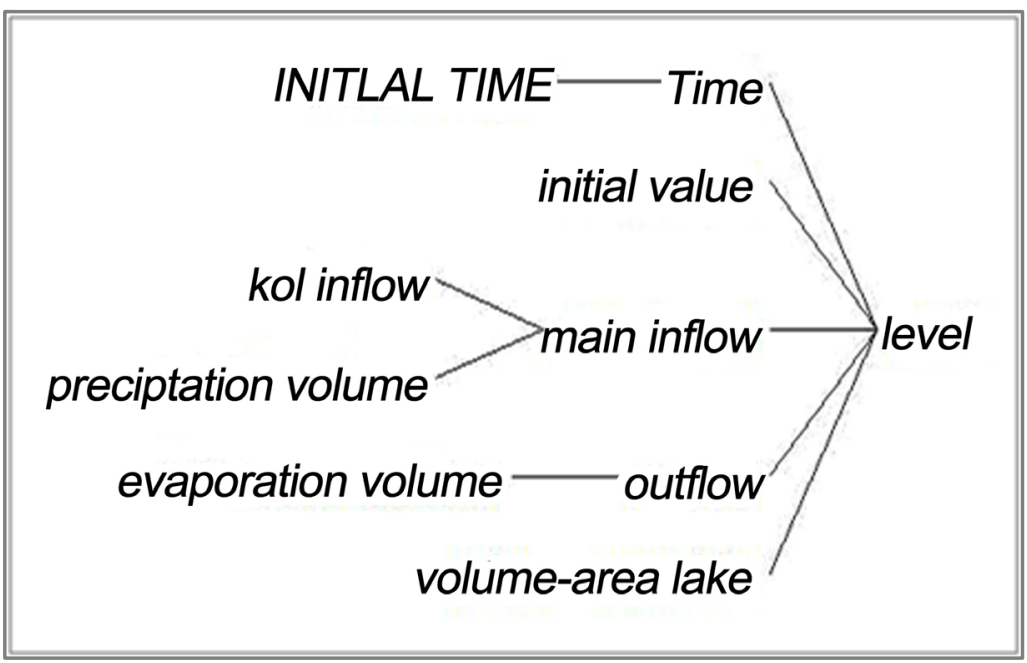

Figure 6. Simulation model of blue expanse surface of the lake.

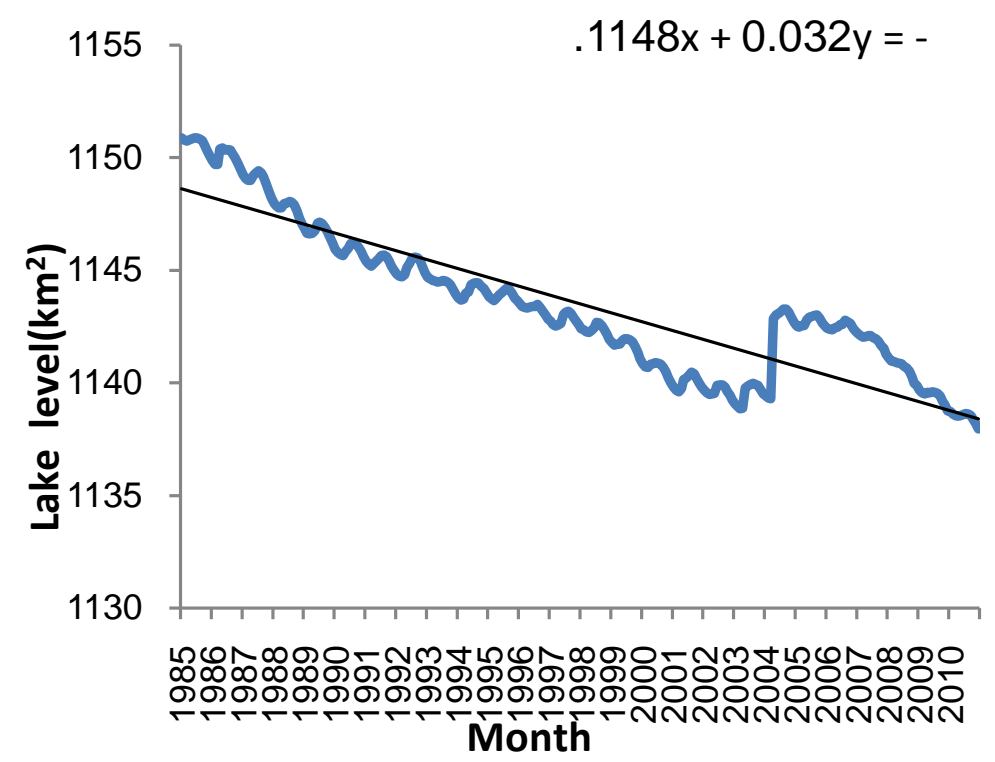

Figure 7. Simulation the area of Tashk and Bakhteganlakes. 
Simulation model of lake surface (Figure 7) showed that the maximum area of expanse of the lake will reach to $1150 / 9$ until 2010 and its minimum will be equal to 1138 meters above sea level and it is observed that during intended period 12/9 square kilometer of the area of the lake has decreased; that indicates significant reduction of the size of the lake.

Linear gradient is negative about flow rate, precipitation and water level and is positive for evaporation and temperature; it means by decreasing rainfall and flow rate on one hand and by increasing evaporation and temperature on the other, lake water level has decreased during the statistical period and finally faced with drying.

\subsubsection{Simulation of Lake's Inflow Model}

To simulate inflow to the lakes, system dynamics model was used based on observed variables and inflow data was defined for model. Model of Figure 8 was used to predict changes of blue expanse water in studied basins, given that in this study the climatic elements have been considered as the main factors and their changes will have effective role on blue expanse changes, data were used in two types include inflow data to the lake [direct rainfall and surface flows] and also evaporation outflow from blue surface in monthly separation during intended period of time, in this regard, at first the number of rivers leading to the lake were extracted and its flow rate measuring station in the nearest place to the lake was indentified, then during 25 years statistical period and in monthly separation the determined codes was defined to the model in the following in order to identify the volume of direct inflow rainfall to the lake the nearest pluviometer station to the lake was used as well; consequently the sum of flow rate to lake and volume of direct precipitation to the lake was calculated. The result from simulation Figure 9 shows the inflow of lake has decreased averagely 0.1 cubic meters per month and 45 cubic meters during statistical period.

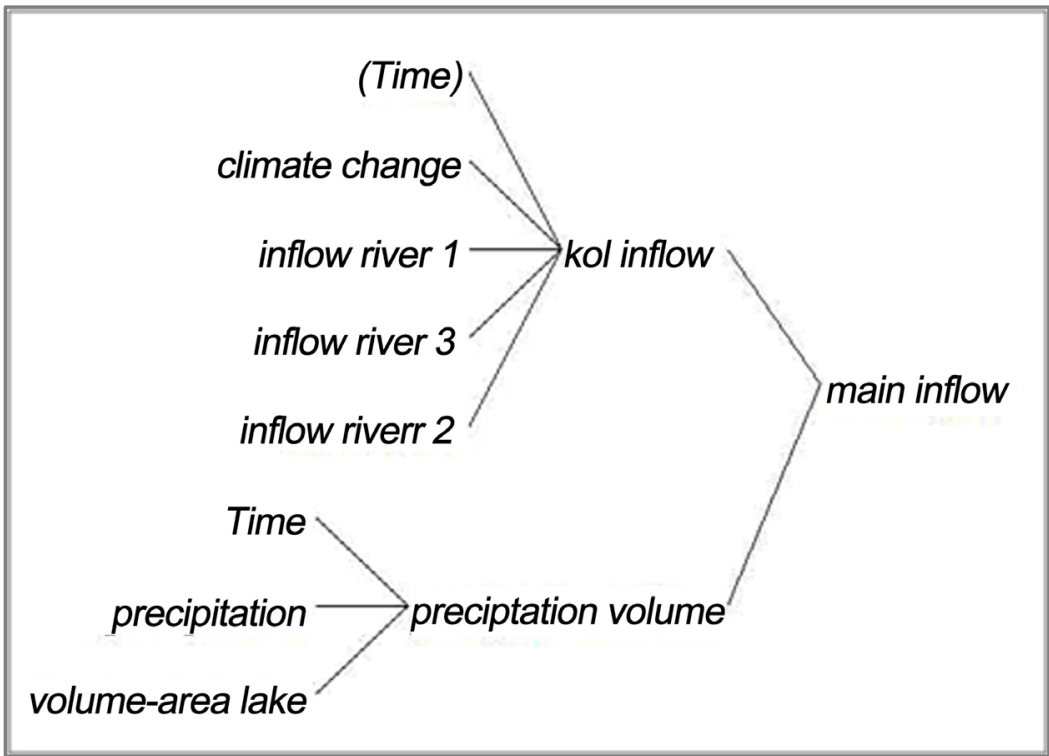

Figure 8. Simulation model of lake inflow. 
2.6.4. Simulation of Evaporation Volume of Tashk and Bakhtegan Lakes Evaporation and transpiration are considered as a climate elements affecting on lake level and its fluctuations which act as a negative factor, monthly data of evaporation and transpiration were multiplied in evaporation pan coefficient of A class of America and in following it was determined given to the defined model of climatic elements role and its fluctuations on lake level and evaporation volume from blue expanse was simulated. These data were also defined with 1 to 360 [tim] code for model of Figure 10 that the result of it indicates the increase of evaporation volume averagely 0.03 in month and 9 millimeter during statistical period. Its outflow is presented in Figure 11.

\section{Conclusions}

Lakes are one of the most important and biggest aquatic ecosystems of Iran that changes in them in systemic and chainlike form will result to expand impact on climate and socio-economic and hydrological conditions and environmental stability. In fact, they have a large impact on their margins as one of the environmental systems and they create an environment that leads to create a kind of

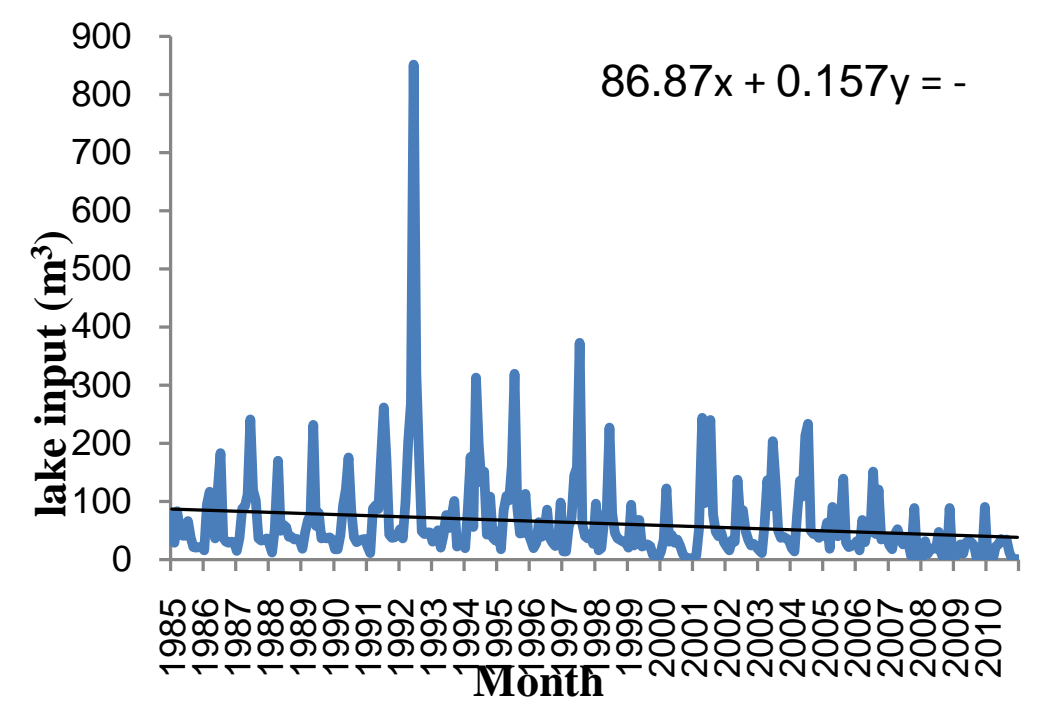

Figure 9. Simulation the inflows of Tashk and Bakhtegan lakes.

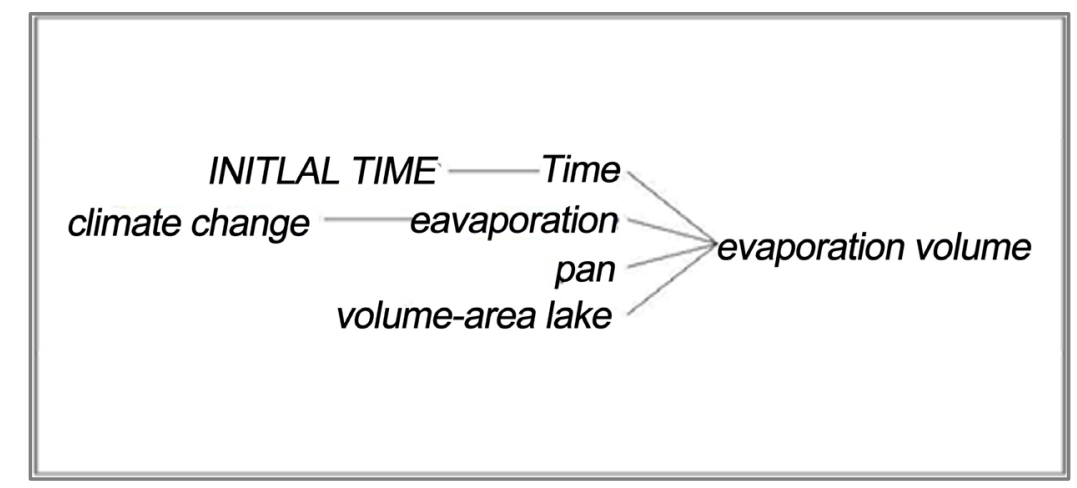

Figure 10. Simulation model of evaporation volume. 


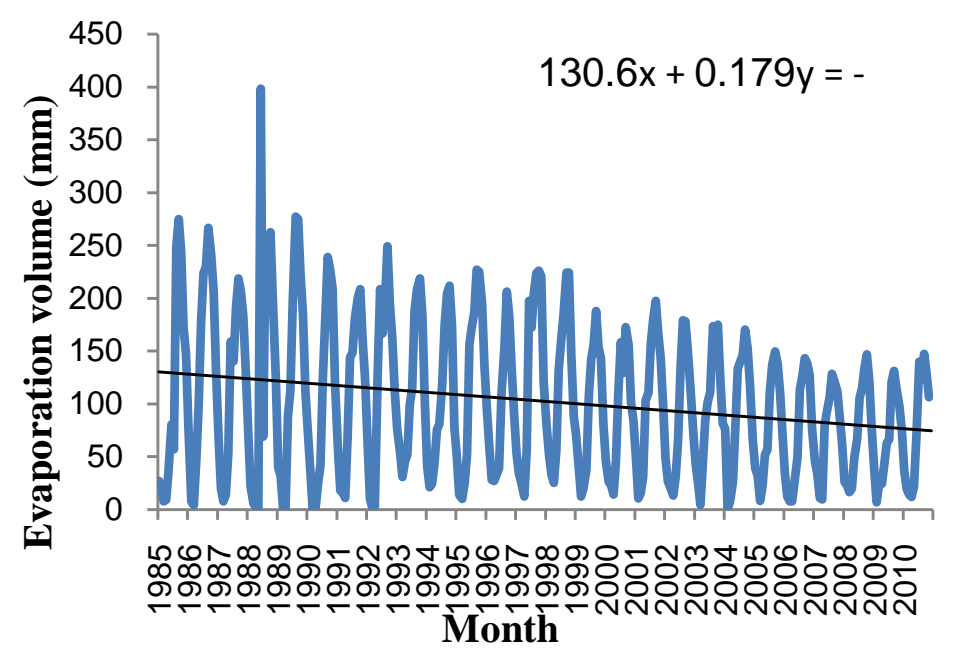

Figure 11. Evaporation volume simulation of Tashk and Bakhtegan lakes.

herding system; regional area and trans-regional climate are also affected by these herding. And following it, drying and tear of lakes will result to changes in ecosystems and geomorphology space and it can provide important consequences. Because the lakes are the most important life productive and biodiversified environment in the world by providing water and capability of reproduction and playing an important role in saving the countless species of plants and animals which are affiliates of their own. Therefore, lakes are considered the reserves of plants and animals genetic material that drying and losing them lead to loss of biodiversity, destroy of flora and fauna and subsequently reducing the capacity of environmental sustainability. It is completely clear that today the quality of human life has failed to instability for reason of these changes. For this reason, the environment of human life under the effect of climate change should be analyzed qualitatively and unstable factors in communities and human environment should be identified. The importance of this matter will be revealed when interaction between biodiversity and climate change is found. In such a way, biodiversity is threatened by climate change while biodiversity can help to reduce change of climate and can lead to increase flexibility of ecosystem in contrast to effects resulted from climate change.

Given that there were many lakes in Iran at late Quaternary that had formed human herding humidity and these lakes have been dried under influence of differrent factors and have been led to changes in environmental ecosystem and environment sustainability capacity reduction, assessing and monitoring the climate change of Tashk and Bakhtegan lakes and its relation with regional climate changes and their role in investigating environmental sustainability have been studied. Thus by using images and calculated flow rate as well as by using rainfall data and estimated temperature under climatic change scenarios and application of vensim network model the blue level of lake was simulated until 2010; simulation of precipitation volume and evaporation volume from lake level indicates inflow reduction, blue expanse reduction, evaporation volume re- 
duction following blue expanse reduction, and represents 12.9 square kilometers reduction of the area of the lake. In other word it was determined that lakes are subjected to significant changes affecting by climatologic changes that are visible in long-term and seasonal scales, such as increase in temperature degree and reduction in rainfall that different climatic consequences have been brought by it and it causes the water level of lakes to be reduced and finally causes the consecutive droughts to be occurred and it has effected on all services of the lakes, and through changes in life cycle it causes imbalance in ecosystems and biodiversity reduction like change in plant coverage and land use, pollutions and attack of invasive species and instability and environmental capacity reduction and since the biodiversity in any region is a key of stability and health of natural environment, destruction of lake's ecosystem which biologically protects the diversity of plant and animal life and is reserve of primary products; the supply of human needs has been faced with problem. But along with many changes in precipitation and temperature, the construction of dams and excessive use of surface and subsurface water resources cannot be ignored that decreasing inflow of the lake causes the drying of Tashk and Bakhtegan lakes to speed up. Generally, loss of more than two-thirds of the area of Tashk and Bakhtegan lakes shows the environmental disaster, for these factors prevent natural balance and harmony in water balance of lakes and a perfect situation has been provided for the emergence of a broad environmental crisis and region is ready to be faced with disastrous natural crisis. Burial of the neighbor lands due to the salt storm resulted from drying of the lake, health and livelihood of residents which is in danger given to the sand and gravel storm, destruction and migration of birds, decrease of rain fed fig cultivation are samples of happened crises that will occur in the future with more intensity.

Therefore, it can be concluded that drying lake is probably due to the combination of human activities and climate changes; in fact lake level reduction can be caused by climate changes, increase of water consumption or changes of provisions patterns. So with all that was mentioned, we should not easily pass through this issue that human development is a major threat for biodiversity and since some of the causes and consequences of climate change may be different in time and space, sometimes such changes are reversible. Therefore, this research has been done to help policymakers, managers and planning as a beginning to investigate to effects of climate change in order a sustainable managemental approach will be ratified for water resources that rivers, lakes and aquatic ecosystems will not so much under pressure, in other words; adapting with climate changes conditions will have a place in decision-making and policy-making of managers, for adaptability and conformity with impacts of these changes, to maintain and flexibility of ecosystem various tensions are required, it is for this reason that effects of atmosphere condition of many of biological processes and behaviors, managemental, economic and socialand underground water and surface water are affected by it and have local, national, regional and trans-regional consequences, therefore; attention of managers and planners in order to basic 
planning and in accordance with development criteria in line with environment in order to improve managemental practices on a macro-level is a vital and inevitable affair.

\section{References}

[1] Abdel-Fattah, S. and Krantzberg, G. (2014) A Review: Building the Resilience of Great Lakes Beneficial Uses to Climate Change. Sustainability of Water Quality and Ecology, 3, 3-13. https://doi.org/10.1016/j.swaqe.2014.11.006

[2] Baker, C., Lawrence, R.L., Montagne, C. and Patten, D. (2007) Change Detection of Wetland Ecosystems Using Landsat Imagery and Change Vector Analysis. Wetlands, 27, 610-619. https://doi.org/10.1672/0277-5212(2007)27[610:cdoweu]2.0.co;2

[3] Bwangoy, J.R.B., Hansen, M.C., Roy, D.P., De Grandi, G. and Justice, C. O. (2010) Wetland Mapping in the Congo Basin Using Optical and Radar Remotely Sensed Data and Derived Topographical Indices. Remote Sensing of Environment, 114, 73 86. https://doi.org/10.1016/j.rse.2009.08.004

[4] Haghighi, A.T. and Kløve, B. (2015) A Sensitivity Analysis of Lake Water Level Response to Changes in Climate and River Regimes. Limnologica-Ecology and Management of Inland Waters, 51, 118-130. https://doi.org/10.1016/j.limno.2015.02.001

[5] International Joint Commission. (2012) Lake Superior Regulation: Addressing Uncertainty in Upper Great Lakes Water Levels. Final Report, 28.

[6] Hui, F., Xu, B., Huang, H., Yu, Q. and Gong, P. (2008) Modelling Spatial-Temporal Change of Poyang Lake Using Multitemporal Landsat Imagery. International Journal of Remote Sensing, 29, 5767-5784. https://doi.org/10.1080/01431160802060912

[7] Hutti, B. and Nijagunappa, R. (2011) Applications of Geoinformatics in Water Resources Management of Semi-Arid Region, North Karnataka, India. International Journal of Geomatics and Geosciences, 2, 373.

[8] Johnson, T.D. and Belitz, K. (2012) A Remote Sensing Approach for Estimating the Location and Rate of Urban Irrigation in Semi-Arid Climates. Journal of Hydrology, 414, 86-98. https://doi.org/10.1016/j.jhydrol.2011.10.016

[9] Bartolai, A.M., He, L., Hurst, A.E., Mortsch, L., Paehlke, R. and Scavia, D. (2015) Climate Change as a Driver of Change in the Great Lakes St. Lawrence River Basin. Journal of Great Lakes Research, 41, 45-58. https://doi.org/10.1016/j.jglr.2014.11.012

[10] Finlayson, C.M., Davis, J.A., Gell, P.A., Kingsford, R.T. and Parton, K.A. (2013) The Status of Wetlands and the Predicted Effects of Global Climate Change: The Situation in Australia. Aquatic Sciences, 75, 73-93. https://doi.org/10.1007/s00027-011-0232-5

[11] Coops, H., Beklioglu, M. and Crisman, T.L. (2003) The Role of Water-Level Fluctuations in Shallow Lake Ecosystems-Workshop Conclusions. Hydrobiologia, 506, 23-27. https://doi.org/10.1023/B:HYDR.0000008595.14393.77

[12] Haghighi, A.T., Marttila, H. and Kløve, B. (2014) Development of a New Index to Assess River Regime Impacts after Dam Construction. Global and Planetary Change, 122, 186-196. https://doi.org/10.1016/j.gloplacha.2014.08.019

[13] Yuan, Y., Zeng, G., Liang, J., Huang, L., Hua, S., Li, F., He, Y., et al. (2015) Variation of Water Level in Dongting Lake over a 50-Year Period: Implications for Impacts of Anthropogenic and Climatic Factors. Journal of Hydrology, 525, 450-456. https://doi.org/10.1016/j.jhydrol.2015.04.010

[14] Haddeland, I., Heinke, J., Biemans, H., Eisner, S., Flörke, M., Hanasaki, N., Stacke, T., et al. (2014) Global Water Resources Affected by Human Interventions and Cli- 
mate Change. Proceedings of the National Academy of Sciences, 111, 3251-3256. https://doi.org/10.1073/pnas.1222475110

[15] Fernandes, L.F.S., dos Santos, C.M.M., Pereira, A.P. and Moura, J.P. (2011) Model of Management and Decision Support Systems in the Distribution of Water for Consumption: Case Study in North Portugal. European Journal of Environmental and Civil Engineering, 15, 411-426. https://doi.org/10.1080/19648189.2011.9693334

[16] Santos, R.M.B., Fernandes, L.S., Moura, J.P., Pereira, M.G. and Pacheco, F.A.L. (2014) The Impact of Climate Change, Human Interference, Scale and Modeling Uncertainties on the Estimation of Aquifer Properties and River Flow Components. Journal of Hydrology, 519, 1297-1314. https://doi.org/10.1016/j.jhydrol.2014.09.001

[17] Brooks, W.R. and Newbold, S.C. (2014) An Updated Biodiversity Nonuse Value Function for Use in Climate Change Integrated Assessment Models. Ecological Economics, 105, 342-349. https://doi.org/10.1016/j.ecolecon.2014.06.015

[18] Pengra, B. (2012) The Drying of Iran's Lake Urmia and Its Environmental Consequences. UNEP-GRID, Sioux Falls, UNEP Global Environmental Alert Service (GEAS).

[19] Hassan, A.A. and Jin, S. (2014) Lake Level Change and Total Water Discharge in East Africa Rift Valley from Satellite-Based Observations. Global and Planetary Change, 117, 79-90. https://doi.org/10.1016/j.gloplacha.2014.03.005

[20] Jin, S. and Feng, G. (2013) Large-Scale Variations of Global Groundwater from Satellite Gravimetry and Hydrological Models, 2002-2012. Global and Planetary Change, 106, 20-30. https://doi.org/10.1016/j.gloplacha.2013.02.008

[21] Moftakhari, H.R., Jay, D.A., Talke, S.A., Kukulka, T. and Bromirski, P.D. (2013) A Novel Approach to Flow Estimation in Tidal Rivers. Water Resources Research, 49, 4817-4832. https://doi.org/10.1002/wrcr.20363

[22] Muvundja, F.A., Wüest, A., Isumbisho, M., Kaningini, M.B., Pasche, N., Rinta, P. and Schmid, M. (2014) Modelling Lake Kivu Water Level Variations over Last Seven Decades. Limnologica-Ecology and Management of Inland Waters, 47, 21-33. https://doi.org/10.1016/j.limno.2014.02.003

[23] Haghighi, A.T., Menberu, M.W., Aminnezhad, M., Marttila, H. and Kløve, B. (2016) Can Lake Sensitivity to Desiccation Be Predicted from Lake Geometry? Journal of Hydrology, 539, 599-610. https://doi.org/10.1016/j.jhydrol.2016.05.064

[24] Mitchell, R.J., Morecroft, M.D., Acreman, M., Crick, H.Q.P., Frost, M., Harley, M., Rehfisch, M.M., et al. (2007) England Biodiversity Strategy-Towards Adapation to Climate Change. Final Report to Defra for Contract CRO327.

[25] Secretariat, C.B.D. (2009) Connecting Biodiversity and Climate Change Mitigation and Adaptation: Report of the Second Ad Hoc Technical Expert Group on Biodiversity and Climate Change, Montreal. Convention on Biological Diversity Technical Series No. 41.

[26] Maclean, I.M. and Wilson, R.J. (2011) Recent Ecological Responses to Climate Change Support Predictions of High Extinction Risk. Proceedings of the National Academy of Sciences, 108, 12337-12342. https://doi.org/10.1073/pnas.1017352108

[27] Pereira, H.M., Leadley, P.W., Proença, V., Alkemade, R., Scharlemann, J.P., Fernandez-Manjarrés, J.F., Chini, L., et al. (2010) Scenarios for Global Biodiversity in the 21st Century. Science, 330, 1496-1501. https://doi.org/10.1126/science.1196624

[28] Thomas, C.D., Cameron, A., Green, R.E., Bakkenes, M., Beaumont, L.J. and Collingham, Y.C. (2004) Extinction Risk from Climate Change. Nature, 427, 145-148. https://doi.org/10.1038/nature02121

[29] Hoffmann, M., Hilton-Taylor, C., Angulo, A., Böhm, M., Brooks, T.M., Butchart, 
S.H., Darwall, W.R., et al. (2010) The Impact of Conservation on the status of the World's Vertebrates. Science, 330, 1503-1509.

https://doi.org/10.1126/science.1194442

[30] Fahrig, L. (2003) Effects of Habitat Fragmentation on Biodiversity. Annual Review of Ecology, Evolution, and Systematics, 34, 487-515. https://doi.org/10.1146/annurev.ecolsys.34.011802.132419

[31] Fischer, J. and Lindenmayer, D.B. (2007) Landscape Modification and Habitat Fragmentation: A Synthesis. Global Ecology and Biogeography, 16, 265-280. https://doi.org/10.1111/j.1466-8238.2007.00287.x

[32] Easterling, D.R., Meehl, G.A., Parmesan, C., Changnon, S.A., Karl, T.R. and Mearns, L.O. (2000) Climate Extremes: Observations, Modeling, and Impacts. Science, 289, 2068-2074. https://doi.org/10.1126/science.289.5487.2068

[33] Heller, N.E. and Zavaleta, E.S. (2009) Biodiversity Management in the Face of Climate Change: A Review of 22 Years of Recommendations. Biological conservation, 142, 14-32. https://doi.org/10.1016/j.biocon.2008.10.006

[34] Barros, V.R., Field, C.B., Dokke, D.J., Mastrandrea, M.D., Mach, K.J., Bilir, T.E., Girma, B., et al. (2014) Climate Change 2014: Impacts, Adaptation, and Vulnerability. Part B: Regional Aspects. Contribution of Working Group II to the Fifth Assessment Report of the Intergovernmental Panel on Climate Change.

[35] Xu, J., Grumbine, R.E., Shrestha, A., Eriksson, M., Yang, X., Wang, Y.U.N. and Wilkes, A. (2009) The Melting Himalayas: Cascading Effects of Climate Change on Water, Biodiversity, and Livelihoods. Conservation Biology, 23, 520-530. https://doi.org/10.1111/j.1523-1739.2009.01237.x

[36] Knutti, R. and Sedláček, J. (2013) Robustness and Uncertainties in the New CMIP5 Climate Model Projections. Nature Climate Change, 3, 369-373. https://doi.org/10.1038/nclimate1716

[37] Chen, I.C., Shiu, H.J., Benedick, S., Holloway, J.D., Chey, V.K., Barlow, H.S., Thomas, C.D., et al. (2009) Elevation Increases in Moth Assemblages over 42 Years on a Tropical Mountain. Proceedings of the National Academy of Sciences, 106, 14791483. https://doi.org/10.1073/pnas.0809320106

[38] Feeley, K.J. and Silman, M.R. (2010) Land-Use and Climate Change Effects on Population Size and Extinction Risk of Andean Plants. Global Change Biology, 16, 3215-3222. https://doi.org/10.1111/j.1365-2486.2010.02197.x

[39] Fuhrer, J. (2003) Agroecosystem Responses to Combinations of Elevated $\mathrm{CO}_{2}$, Ozone, and Global Climate Change. Agriculture, Ecosystems \& Environment, 97, 1-20. https://doi.org/10.1016/S0167-8809(03)00125-7

[40] Arsanjani, T.J., Javidan, R., Nazemosadat, M.J., Arsanjani, J.J. and Vaz, E. (2015) Spatiotemporal Monitoring of Bakhtegan Lake's Areal Fluctuations and an Exploration of Its Future Status by Applying a Cellular Automata Model. Computers \& Geosciences, 78, 37-43. https://doi.org/10.1016/j.cageo.2015.02.004

[41] Hesslerová, P. and Šíma, M. (2010) Method for Detection of Small Water Bodies Developed for Purpose of Cage Fish Farming in Eastern Africa.

[42] Arsanjani, J.J., Helbich, M. and Mousivand, A.J. (2014) A Morphological Approach to Predicting Urban Expansion. Transactions in GIS, 18, 219-233. https://doi.org/10.1111/tgis.12031

[43] Kahl, U., Hülsmann, S., Radke, R.J. and Benndorf, J. (2008) The Impact of Water Level Fluctuations on the Year Class Strength of Roach: Implications for Fish Stock Management. Limnologica-Ecology and Management of Inland Waters, 38, 258268. https://doi.org/10.1016/j.limno.2008.06.006 
[44] Erdinger, L., Hollert, H. and Eckl, P. (2011) Aral Sea: An Ecological Disaster Zone with Impact on Human Health. Encyclopedia of Environmental Health.

[45] Glantz, M.H. (2007) Aral Sea Basin: A Sea Dies, a Sea Also Rises. Ambio, 36, 323 327. https://doi.org/10.1579/0044-7447(2007)36[323:ASBASD]2.0.CO;2

[46] Kamalov, Y. (2003) The Aral Sea: Problems, Legends, Solutions. Water Science and Technology, 48, 225-231.

[47] Zavialov, P.O., Kostianoy, A.G., Emelianov, S.V., Ni, A.A., Ishniyazov, D., Khan, V.M. and Kudyshkin, T.V. (2003) Hydrographic Survey in the Dying Aral Sea. Geophysical Research Letters, 30, 1659-1662. https://doi.org/10.1029/2003GL017427

[48] Coe, M.T. and Foley, J.A. (2001) Human and Natural Impacts on the Water Resources of the Lake Chad Basin. Journal of Geophysical Research: Atmospheres, 106, 3349-3356. https://doi.org/10.1029/2000JD900587

[49] Guganesharajah, K. and Shaw, E.M. (1984) Forecasting Water Levels for Lake Chad. Water Resources Research, 20, 1053-1065. https://doi.org/10.1029/WR020i008p01053

[50] Bedford, D. (2009) The Great Salt Lake America's Aral Sea? Environment. Science and Policy for Sustainable Development, 51, 8-21. https://doi.org/10.3200/ENVT.51.5.8-21

[51] Stephens, D.W. (1990) Changes in Lake Levels, Salinity and the Biological Community of Great Salt Lake (Utah, USA), 1847-1987. In: Comín, F.A. and Northcote, T.G., Eds., Saline Lakes, Springer, Berlin, 139-146. https://doi.org/10.1007/978-94-009-0603-7_13

[52] Khan, Q.J.A., Balakrishnan, E. and Al Harthi, A.H. (2013) Eco-Epidemiological Models of Salton Sea with Infected Prey. Journal of Biological Systems, 21, 1350003. https://doi.org/10.1142/S0218339013500034

[53] Paillisson, J.M. and Marion, L. (2011) Water Level Fluctuations for Managing Excessive Plant Biomass in Shallow Lakes. Ecological Engineering, 37, 241-247. https://doi.org/10.1016/j.ecoleng.2010.11.017

[54] Mistry, V.V. and Conway, D. (2003) Remote Forcing of East African Rainfall and Relationships with Fluctuations in Levels of Lake Victoria. International Journal of Climatology, 23, 67-89. https://doi.org/10.1002/joc.861

[55] Guo, H., Jiang, T., Wang, G., Su, B. and Wang, Y. (2006) Observed Trends and Jumps of Climate Change over Lake Poyang Basin, China: 1961-2003. Journal of Lake Sciences, 18, 443-451. https://doi.org/10.18307/2006.0501

[56] Mendoza, M.E., Bocco, G., Bravo, M., Granados, E.L. and Osterkamp, W.R. (2006) Predicting Water-Surface Fluctuation of Continental Lakes: A RS and GIS Based Approach in Central Mexico. Water Resources Management, 20, 291-311. https://doi.org/10.1007/s11269-006-8199-z

[57] Ryner, M., Gasse, F., Rumes, B. and Verschuren, D. (2007) Climatic and Hydrological Instability in Semi-Arid Equatorial East Africa during the Late Glacial to Holocene Transition: A Multi-Proxy Reconstruction of Aquatic Ecosystem Response in Northern Tanzania. Palaeogeography, Palaeoclimatology, Palaeoecology, 248, 440458. https://doi.org/10.1016/j.palaeo.2006.12.014

[58] Motiee, H. and McBean, E. (2009) An Assessment of Long-Term Trends in Hydrologic Components and Implications for Water Levels in Lake Superior. Hydrology Research, 40, 564-579. https://doi.org/10.2166/nh.2009.061

[59] Zilefac, E.A. (2010) Analysis of Climate Variability and Anthropogenic Impacts on the Water Balance of Lake Chad Drainage Basin. 
[60] Njaya, F., Snyder, K.A., Jamu, D., Wilson, J., Howard-Williams, C., Allison, E.H. and Andrew, N.L. (2011) The Natural History and Fisheries Ecology of Lake Chilwa, Southern Malawi. Journal of Great Lakes Research, 37, 15-25.

https://doi.org/10.1016/j.jglr.2010.09.008

[61] Huang, S., Dahal, D., Young, C., Chander, G. and Liu, S. (2011) Integration of Palmer Drought Severity Index and Remote Sensing Data to Simulate Wetland Water Surface from 1910 to 2009 in Cottonwood Lake Area, North Dakota. Remote Sensing of Environment, 115, 3377-3389. https://doi.org/10.1016/j.rse.2011.08.002

[62] Mekonnen, M.M., Hoekstra, A.Y. and Becht, R. (2012) Mitigating the Water Footprint of Export Cut Flowers from the Lake Naivasha Basin, Kenya. Water Resources Management, 26, 3725-3742. https://doi.org/10.1007/s11269-012-0099-9

[63] Zawiska, I., Słowiński, M., Correa-Metrio, A., Obremska, M., Luoto, T., Nevalainen, L., Milecka, K., et al. (2015) The Response of a Shallow Lake and Its Catchment to Late Glacial Climate Changes-A Case Study from Eastern Poland. Catena, 126, 110. https://doi.org/10.1016/j.catena.2014.10.007

Submit or recommend next manuscript to SCIRP and we will provide best service for you:

Accepting pre-submission inquiries through Email, Facebook, LinkedIn, Twitter, etc. A wide selection of journals (inclusive of 9 subjects, more than 200 journals)

Providing 24-hour high-quality service

User-friendly online submission system

Fair and swift peer-review system

Efficient typesetting and proofreading procedure

Display of the result of downloads and visits, as well as the number of cited articles

Maximum dissemination of your research work

Submit your manuscript at: http://papersubmission.scirp.org/

Or contact oje@scirp.org 